\title{
Nutritional status of the potted chrysanthemum relative to electrical conductivity and salt leaching ${ }^{1}$
}

\author{
Estado nutricional do crisântemo de vaso em função da condutividade elétrica e \\ lixiviação de sais
}

\author{
Márkilla Zunete Beckmann-Cavalcante ${ }^{2 *}$, Kathia Fernandes Lopes Pivetta ${ }^{3}$, Ítalo Herbert Lucena Cavalcante ${ }^{2}$, \\ Lourival Ferreira Cavalcante e José Valdenor da Silva Júnior $^{5}$
}

\begin{abstract}
The quality of ornamental plants grown in pots is highly dependent on fertilization and substrate management. To this effect, we carried out an experiment in a protected environment to evaluate the nutritional status of the chrysanthemum cv. Miramar grown in pots, relative to the electrical conductivity of the nutrient solution and the leaching of salts. The experimental design was of randomized blocks with four replications and the treatments arranged in a $5 \times 2$ factorial, relating to the levels of electrical conductivity of the nutrient solution $\left(\mathrm{ECs}=2.1 ; 2.8 ; 3.5 ; 4.2\right.$ and $\left.4.9 \mathrm{dS} \mathrm{m}^{-1}\right)$ in substrates without (SNL) and with (SWL) washing for the leaching of salts. The nutritional status of the plants was evaluated by leaf analysis of macronutrients $(\mathrm{N}$, $\mathrm{P}, \mathrm{K}, \mathrm{Ca}, \mathrm{Mg}$ and $\mathrm{S}$ ) and micronutrients $(\mathrm{Cu}, \mathrm{Fe}, \mathrm{Mn}$ and $\mathrm{Zn})$. The increase in ECs inhibited the accumulation of micronutrients and of nitrogen, but stimulated the levels of $\mathrm{P}, \mathrm{K}, \mathrm{Ca}, \mathrm{Mg}$ and $\mathrm{S}$ in the leaf dry mass of the chrysanthemum. The leaching of salts increased the concentration $\mathrm{Cu}, \mathrm{Fe}$ and $\mathrm{Mn}$ in the plant leaves. Among the macronutrients, with the except of calcium and sulphur, no significant difference was observed for $\mathrm{N}, \mathrm{P}, \mathrm{K}$ and $\mathrm{Mg}$ relative to the leaching of salts.
\end{abstract}

Key words: Dendranthema grandiflora Tzvelev. Substrate. Plant nutrition.

RESUMO - A qualidade das plantas ornamentais cultivadas em vaso é altamente dependente da adubação e do manejo do substrato. Nesse sentido, realizou-se um experimento em ambiente protegido para avaliar o estado nutricional do crisântemo cv. Miramar cultivado em vaso em função da condutividade elétrica da solução nutritiva e lixiviação de sais. O delineamento experimental foi em blocos casualizados, em quatro repetições, com os tratamentos distribuídos em esquema fatorial $5 \times 2$, referentes aos níveis de condutividade elétrica da solução nutritiva (CEs $=2,1 ; 2,8 ; 3,5 ; 4,2$ e 4,9 dS m m $^{-1}$ em substrato sem (SSL) e com (SCL) lavagem para lixiviação dos sais. O estado nutricional das plantas foi avaliado pela análise foliar de macro $(\mathrm{N}, \mathrm{P}, \mathrm{K}, \mathrm{Ca}, \mathrm{Mg}$ e $\mathrm{S})$ e micronutrientes $(\mathrm{Cu}, \mathrm{Fe}, \mathrm{Mn}$ e $\mathrm{Zn})$. O aumento da CEs inibiu o acúmulo de micronutrientes e de nitrogênio, mas estimulou os teores de $\mathrm{P}, \mathrm{K}, \mathrm{Ca}, \mathrm{Mg}$ e $\mathrm{S}$ na massa seca foliar do crisântemo. A lixiviação dos sais promoveu maior acúmulo foliar de $\mathrm{Cu}, \mathrm{Fe}$ e $\mathrm{Mn}$ nas plantas. Dentre os macronutrientes, exceção feita ao cálcio e enxofre, não ocorreu diferença significativa para N, P, K e Mg quanto à lixiviação de sais.

Palavras-chave: Dendranthema grandiflora Tzvelev. Substrato. Nutrição de plantas.

\footnotetext{
*Autor para correspondência

'Recebido para publicação em 19/09/2011; aprovado em 23/06/2013

Parte da Tese de Doutorado da primeira autora apresentada à Faculdade de Ciências Agrárias e Veterinárias/FCAV, Universidade Estadual Paulista "Júlio de Mesquita"/UNESP

${ }^{2}$ Campus de Ciências Agrárias, Universidade Federal do Vale do São Francisco, Petrolina-PE, Brasil, markilla.beckmann@ univasf.edu.br, italo. cavalcante@univasf.edu.br

${ }^{3}$ Departamento de Produção Vegetal, Faculdade de Ciências Agrárias e Veterinárias, Universidade Estadual Paulista "Júlio de Mesquita", Jaboticabal-SP, Brasil, kathia@fcav.unesp.br

${ }^{4}$ Departamento de Solos e Engenharia Rural, Centro de Ciências Agrárias, Universidade Federal da Paraíba, Areia-PB, Brasil, lofeca@ufpb.br

${ }_{5}^{5}$ Departamento de Engenharias, Campus Profa. Cinobelina Elvas/Universidade Federal do Piauí, Programa de Pós-Graduação em Solos e Nutrição de Plantas, Bom Jesus-PI, Brasil, valdenor.jr@ufpi.edu.br
} 


\section{INTRODUCTION}

Floriculture has emerged as one of the most dynamic and advanced sectors of contemporary agribusiness, and although growing, Brazil's participation in the international flower trade is still in its infancy. The Instituto de Economia Agrícola (Institute of Agricultural Economics - IEA) of the State of São Paulo monitors the development of domestic flower farming, and from their data it can be seen that in 2009 the country exported an amount of flowers equivalent to USD 31.5 million (KIUNA; ANGELO; COELHO 2010).

Among the major domestic products of flower farming, the chrysanthemum (Dendranthema grandiflora Tzvelev.) stands out both as a potted plant and as cut flowers (JUNQUEIRA; PEETZ, 2008). According Roude, Nell e Barret (1991), the commercial value of the chrysanthemum is directly related to the size and quality of the leaves, stems and flower clusters, and success in the production of plants with these characteristics is associated with environmental and nutritional conditions, i.e. the quality is highly dependent on fertilization and substrate management.

For plants grown in pots, substrates are used as a culture medium, restricting the volume exploited by the root system and making it necessary to apply nutrient solutions with the appropriate concentrations of nutrients for the plants. However when growing flowers in pots, under managements employing fertigation, a large part of producers follow previously-established patterns of fertilization, often leading them to produce plants of low quality (BECKMANN-CAVALCANTE et al., 2010). The difficulty in implementing chrysanthemum cultivation is in quantifying the levels of fertilizer to be applied according to the nutritional requirements of the crop, as stated by Fernandes et al. (2008). To this effect, incorrect management of the nutrient solution can promote a nutritional imbalance in the plants, and even an increase in electrical conductivity reflected in a rise in the salinity of the substrate beyond the tolerance limit of the crop, with consequent toxicity problems resulting in losses in the productivity and quality of the product (CAVALCANTE et al., 2002).

According to Giuffrida and Lipari (2003), and Ferreira et al. (2007), one of the ways to control the accumulation of salts in the soil or substrate is periodically to apply amounts of water to leach the salts present in the nutrient solution supplied to the plants so that they do not accumulate in the root environment. Once periodic monitoring has been established, the concentration of fertilizers applied via the irrigation water, in most cases on a daily basis, can be controlled in such a way as to maintain concentration of the solution in the soil or substrate within an appropriate EC range, ensuring a sufficient availability of nutrients to the plants without greater risk of osmotic problems. On the other hand, applying the amount of fertilizer required by the crop could attend to the nutrient demands of the plants without causing an excess of salts in the soil or substrate.

According to Flowers (2004), Munns (2002) and Yokoi, Bressan and Hasegawa (2002), the immediate effects of excess salts on the plants are a decrease in osmotic potential, in nutritional imbalance due to the high ionic concentration, and in the toxicity of some ions, such as chloride and sodium.

Considering the above, the present study was carried out with the objective of evaluating the nutritional status of the chrysanthemum 'Miramar' when cultivated in pots, relative to the electrical conductivity of the nutrient solution and leaching of salts, under the conditions of Jaboticabal, São Paulo.

\section{MATERIAL AND METHODS}

The experiment was conducted in a greenhouse of the Plasticulture Sector of the Department of Rural Engineering, the Faculty of Agricultural and Veterinary Sciences (FCAV) of the Paulista State University 'Júlio de Mesquita Filho’ (UNESP), Jaboticabal, São Paulo, located at $21^{\circ} 14^{\prime} 05^{\prime}$ 'S $48^{\circ} 17^{\prime} 09^{\prime \prime} \mathrm{W}$, at an average altitude of $600 \mathrm{~m}$.

A gable greenhouse was used as the protected environment, with a total area of $510 \mathrm{~m}^{2}(10 \times 51 \mathrm{~m})$ and ceiling height of $3 \mathrm{~m}$, set East-West, on a metal frame, covered with transparent polyethylene film, UV treated and with a thickness of 150 microns. The sides were protected with $30 \%$ shade screens in polypropylene, $1 \mathrm{~m}$ high, and the area occupied by the chrysanthemum pots was covered with a $50 \%$ shade screen.

During the experiment, the average temperature inside the protected environment was $23.2^{\circ} \mathrm{C}$, the average minimum temperature was $19.1{ }^{\circ} \mathrm{C}$ and the average maximum temperature was $31.6^{\circ} \mathrm{C}$. For the same period, the average relative humidity of the air was $74.4 \%$, the minimum average $47 \%$ and the maximum average $92 \%$.

The experimental design was of randomized blocks with treatments arranged in a $5 \times 2$ factorial, corresponding to the levels of electrical conductivity (EC) of the nutrient solution $\left(2.1 ; 2.8 ; 3.5 ; 4.2\right.$ and $\left.4,9 \mathrm{dS} \mathrm{m}^{-1}\right)$ in a substrate with (SWL) and with no (SNL) washing with distilled water in order to leach the substrate salts, and four replications.

Cuttings of chrysanthemum (Dendranthema grandiflora Tzvelev.) 'Miramar', yellow in colour and having daisy-type inflorescences, originating from a single batch of the same age, and treated with indolebutyric acid 
(IBA), were acquired from the commercial Dekker de Wit ${ }^{\circledR}$ company, and grown in number 14 polyethylene pots, having a volume of $1.2 \mathrm{~L}$ (height $12 \mathrm{~cm}$, upper and lower base of $14 \mathrm{~cm}$ and $9.4 \mathrm{~cm}$ diameter respectively) and containing a commercial substrate for ornamental plants (Terra do Paraíso 3010).

Six cuttings were grown per pot, which after planting were covered with plastic to keep moisture in during rooting. At 14 days after the start of rooting, upon their presenting five or six open leaves, and roots reaching a depth of at least $6 \mathrm{~cm}$ (half the height of the pot, checked daily), they underwent lopping (pinching), to remove the apical meristem and stimulate the emergence of side shoots, promoting better plant formation. At that stage, those pots that were side by side, were spaced out $(30 \times 30 \mathrm{~cm})$ in order to promote the growth and development of the plants, with this date being considered as evaluation time 0 (zero).

During rooting, period artificial lighting was provided, giving days with more than 13 hours of light, by employing $100 \mathrm{~W}$ incandescent lamps, installed at a height of $1.2 \mathrm{~m}$, and spaced $1.0 \times 1.0 \mathrm{~m}$ apart. These were turned on at night, automatically switching between intervals of light and darkness to encourage vegetative growth. This operation was performed daily until the 14th day after rooting (DAR). After this period, the plants went onto short days (days with less than 13 hours of light) in order to induce flowering, using the artificial darkness produced by black polyethylene tarpaulins. This management gave a total of 12 weeks' cultivation.

The pots were kept free of weeds, and preventive pest control was carried out based on products and levels appropriate to the crop, using Imidacloprid (70\%) for the prevention of whitefly and Deltamethrin $(25 \%)$ to control leafminer. The growth regulator BNine ${ }^{\circledR}$ (Daminozide $85 \%$ ) at $2 \mathrm{~g} \mathrm{~L}^{-1}$ was applied three times during the cycle, at 14, 28 and 42 DAR.

The fertigation management was based on the weight method, in which five pots from each treatment, with drainage at the bottom, were initially saturated with non-saline water until drainage began. Once drainage ceased the pots were weighed in order to get the initial wet weight (Ui) corresponding to the capacity of the pot. In this way the value of the pot + wet substrate + plant was obtained for each treatment; this was used as a reference for further irrigations until the end of the experiment. To replace the amount of solution (QS) consumed (through evapotranspiration) the previous day, the pots were weighed again, and the final average humidity (Uf) calculated using the equation $\mathrm{QS}=\mathrm{Ui}$ - Uf, the volumes of water to be applied in each treatment being arrived at. The vessels were weighed daily and always at the same time. For the complete crop cycle with the SNL treatment, at $14 ; 28 ; 42 ; 56$ and 70 DAR, 180; 200; 233; 244 and $249 \mathrm{~mL}$ / pot day ${ }^{-1}$ of nutrient solution respectively were consumed (with a mean of $221 \mathrm{~mL} /$ pot day $^{-1}$ ), and for the SWL treatment, 181, 217, 254, 266 and $271 \mathrm{~mL} /$ pot day ${ }^{-1}$ (with a mean of $237 \mathrm{~mL} /$ pot day ${ }^{-1}$ ). In the SWL treatment the amount of distilled water applied for leaching the salts was not considered in the total consumption.

To estimate the values for the EC of the nutrient solution and of the total amount of dissolved salts, a nutrient solution which had been previously tested (BECKMANN-CAVALCANTE et al., 2009) was used. This contains the macronutrients $\left(\mathrm{mg} \mathrm{L}^{-1}\right): 200 \mathrm{~N} ; 31$ $\mathrm{P} ; 293 \mathrm{~K} ; 100 \mathrm{Ca} ; 24 \mathrm{Mg} ; 32 \mathrm{~S}$; and the micronutrients (mg L-1): $0.2 \mathrm{~B}$; $0.03 \mathrm{Cu} ; 3.4 \mathrm{Fe}, 1.1 \mathrm{Mn}$; $0.05 \mathrm{Mo}$; and $0.2 \mathrm{Zn}$. The EC values for the nutrient solutions were obtained from the increasing proportional change in concentration of each nutrient, by diluting with rainwater $\left(\mathrm{EC}=0.07 \mathrm{dS} \mathrm{m}^{-1}\right)$ until reaching the desired $\mathrm{EC}$ as follows: $1=\mathrm{EC} 1$, reference solution; $2=\mathrm{EC} 2$, with an increase of $33.33 \%$ of EC1; $3=\mathrm{EC} 3$, with an increase of $66.66 \%$ of EC1, 4= EC4, with an increase of $100 \%$ of EC1, and $5=\mathrm{EC} 5$, with an increase of $133.33 \%$ of EC1.

The following were used as a source of nutrients for making up the nutrient solutions: Ammonium nitrate (NH4NO3); calcium nitrate $(\mathrm{Ca}(\mathrm{NO} 3) 2)$; potassium nitrate (KNO3); magnesium sulphate (MgSO4); monoammonium phosphate (MAP); Profol® (B 10\%, Cu 14\%, Mn 14\%, Mo $12 \%$ and $\mathrm{Zn} 24 \%$ ); and Rexene $\AA$ (6.5\% iron chelate EDTA). To avoid any imbalance in the nutrient solutions, the $\mathrm{EC}$ and $\mathrm{pH}$ values were monitored weekly.

In those treatments whichincluded leaching, washing the substrate was carried out every 14 days, following the PourThru method as described by Cavins et al. (2000). Initially, daily irrigation using nutrient solution was done, leaving the substrate saturated; one hour later $100 \mathrm{~mL}$ of distilled water were added to the pots. Plastic receptacles were placed under four pots from each treatment to collect the leached solution so as to read the $\mathrm{pH}$ and $\mathrm{EC}$, according to recommendations by the same author.

The nutritional status of the plants was evaluated by leaf analysis of the macronutrients $(\mathrm{N}, \mathrm{P}, \mathrm{K}, \mathrm{Ca}, \mathrm{Mg}$ and $\mathrm{S}$ ) and micronutrients ( $\mathrm{Cu}, \mathrm{Fe}, \mathrm{Mn}$ and $\mathrm{Zn})$, at $70 \mathrm{DAR}$. The leaf samples were washed successively in a detergent solution $(0.1 \% \mathrm{v} / \mathrm{v})$, water and then distilled water, and dried in a forced-air circulation oven at $70{ }^{\circ} \mathrm{C}$ until reaching a constant weight. After drying the samples were ground in a Wiley mill having a stainless steel chamber and $1 \mathrm{~mm}$ sieve, stored in airtight plastic containers and sent to the Central Laboratory of UNESP / FCAV for chemical analysis (MALAVOLTA; VITTI; OLIVEIRA, 1997).

The data were subjected to variance analysis in order to verify the statistical effects of isolated factors 
and the interactions between them. The averages of the factors for substrate-leaching were compared by Tukey test $(\mathrm{P}<0.01)$ employing the SAS software (SAS, 2000), and those of the electrical conductivity of the substrate, by polynomial regression with the SigmaPlot software (SPSS, 2000).

\section{RESULTS AND DISCUSSION}

From the results of the variance analysis shown in Table 1, it can be seen that only concentrations of the macronutrients calcium $(\mathrm{Ca})$ and sulphur $(\mathrm{S})$ were statistically influenced by leaching. For levels of electrical conductivity of the nutrient solution (ECs) a significant statistical difference was seen in the macronutrients, phosphorus $(\mathrm{P})$, potassium $(\mathrm{K})$ and calcium $(\mathrm{Ca})$. The interaction of substrate leaching with the electrical conductivity of the solution did not statistically affect the foliar macronutrient levels in the chrysanthemum.

The increase in the electrical conductivity of the solution inhibited the absorption and accumulation of nitrogen $(\mathrm{N})$ by the chrysanthemum plants (Figure 1A). The reduction between the values for those treatments irrigated with solutions of the lowest and highest ECs was low, approximately $4.0 \%$. As described by Marschner (2005), this decrease may be due to the competition for active sites between monovalent cations $(\mathrm{K}+$ and $\mathrm{NH} 4+$, in the present study) due to the greater amount of potassium required by the crop and consequently supplied from the nutrient solution. Regardless of the decrease in concentration, all the ECs promoted sufficient levels of the element (3.77 to $3.91 \%$ ), when compared to the amounts of $3.50 \%$ to $5.00 \%$ (SCHOENMAKER, 1997) and 3.00 to $5.00 \%$ (JONES; WOLF; MILLS, 1991), suggested as the average $\mathrm{N}$ content of chrysanthemum leaves.
Similar results regarding concentrations of $\mathrm{N}$ were obtained by Roude, Nell e Barret (1991), finding the value of $3.70 \%$ in leaves of the chrysanthemum "Iridon", grown under a fertigation system. Whereas Barbosa et al. (2008) using the varieties White Diamond, Yellow Diamond, Red Delano and Charm, grown in pots under fertigation, found values of $\mathrm{N}$ of 4.17, 4.76, 4.20 and $4.05 \%$ respectively, and Barbosa et al. (2009), in a hydroponic crop of cut chrysanthemum, obtained for Dark Flamengo, Calabria and Blusch Hawaii, average values of $4.28,3.08$ and $4.11 \%$ respectively.

For phosphorus (P), a gradual increase in the concentration of the nutrient was recorded for an increase in the ECs, until reaching $3.5 \mathrm{dS} \mathrm{m}^{-1}$, followed by a sharp rise up to the last EC value (Figure 1B). Considering the chrysanthemum is a species with a high nutritional requirement and low sensitivity to salts (PENNINGSFELD, 1962), the results in this case are consistent with those presented by $\mathrm{Hu}$ and Schmidhalter (2005) when asserting that salinity can increase the concentration of this element, actually being able to induce toxicity. Bosco et al. (2009) studying the influence of salt stress on the composition of the eggplant, observed that phosphorus content in the leaves and roots increased in proportion to the increase in the levels of salts in the solutions. According to Lana et al. (2004) and Rodrigues et al. (2004), phosphorus deficiency restricts the growth of plants. However, although the concentrations shown in Figure 1B are classified as "sufficient" by Schoenmaker (1997), i.e. from 0.23 to $0.70 \%$, visual symptoms, such as reduced growth and a delay in the flower-opening process, although normal, were observed in those plants irrigated with ECs $4.9 \mathrm{dS} \mathrm{m}^{-1}$.

Table 1 - Concentration of macronutrients in the aerial part of chrysanthemum plants cv. "Miramar", as a function of leaching of the substrate solution (L), and the values for electrical conductivity of the nutrient solution (ECs). Jaboticabal, São Paulo

\begin{tabular}{|c|c|c|c|c|c|c|}
\hline \multirow{2}{*}{ Cause of variation } & $\mathrm{N}$ & $\mathrm{P}$ & $\mathrm{K}$ & $\mathrm{Ca}$ & $\mathrm{Mg}$ & $\mathrm{S}$ \\
\hline & \multicolumn{6}{|c|}{ 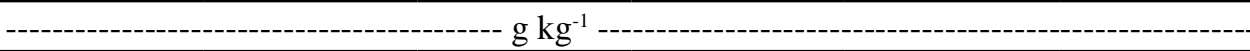 } \\
\hline Leaching (L) ("F") & $2.47^{\mathrm{ns}}$ & $1.34^{\mathrm{ns}}$ & $2.01^{\mathrm{ns}}$ & $5.20 *$ & $0.10^{\mathrm{ns}}$ & $7.14 *$ \\
\hline SNL & $3.88 \mathrm{a}$ & $0.62 \mathrm{a}$ & $4.04 \mathrm{a}$ & $1.30 \mathrm{a}$ & $0.51 \mathrm{a}$ & $0.60 \mathrm{a}$ \\
\hline SWL & $3.80 \mathrm{a}$ & $0.56 \mathrm{a}$ & $4.33 \mathrm{a}$ & $1.24 \mathrm{~b}$ & $0.52 \mathrm{a}$ & $0.56 \mathrm{~b}$ \\
\hline MSD & 0.12 & 0.12 & 0.45 & 0.06 & 0.03 & 0.03 \\
\hline ECs ("F" value) & $0.76^{\mathrm{ns}}$ & $0.06^{*}$ & $5.69 *$ & $17.93 * *$ & $1.22^{\mathrm{ns}}$ & $1.11^{\mathrm{ns}}$ \\
\hline Interraction L x ECs & $0.73^{\mathrm{ns}}$ & $0.36^{\mathrm{ns}}$ & $0.19^{\mathrm{ns}}$ & $3.13^{\mathrm{ns}}$ & $1.54^{\mathrm{ns}}$ & $1.26^{\mathrm{ns}}$ \\
\hline $\mathrm{CV}(\%)$ & 3.08 & 20.22 & 0.81 & 4.56 & 6.69 & 5.60 \\
\hline
\end{tabular}

"F" = F value; $* *=$ significant at a $1 \%$ level of probability $(\mathrm{p}<0.01) ; *$ significant at a $5 \%$ level of probability $(0.01<\mathrm{p}<0.05) ; \mathrm{ns}=$ non-significant ( $>0.05) ; \mathrm{MSD}=$ minimum significant distance; $\mathrm{CV}=$ coefficient of variation; $\mathrm{SNL}=$ substrate with no leaching; $\mathrm{SWL}=$ substrate with leaching; ECs $=$ electrical conductivity of the nutrient solution 
Figure 1 - Concentration of nitrogen (A), phosphorus (B), potassium (C), calcium (D), magnesium (E) and sulphur (F) in the aerial part of chrysanthemum plants cv. "Miramar" at 70 DAR, as a function of the values for electrical conductivity of the nutrient solution (ECs). Jaboticabal, São Paulo
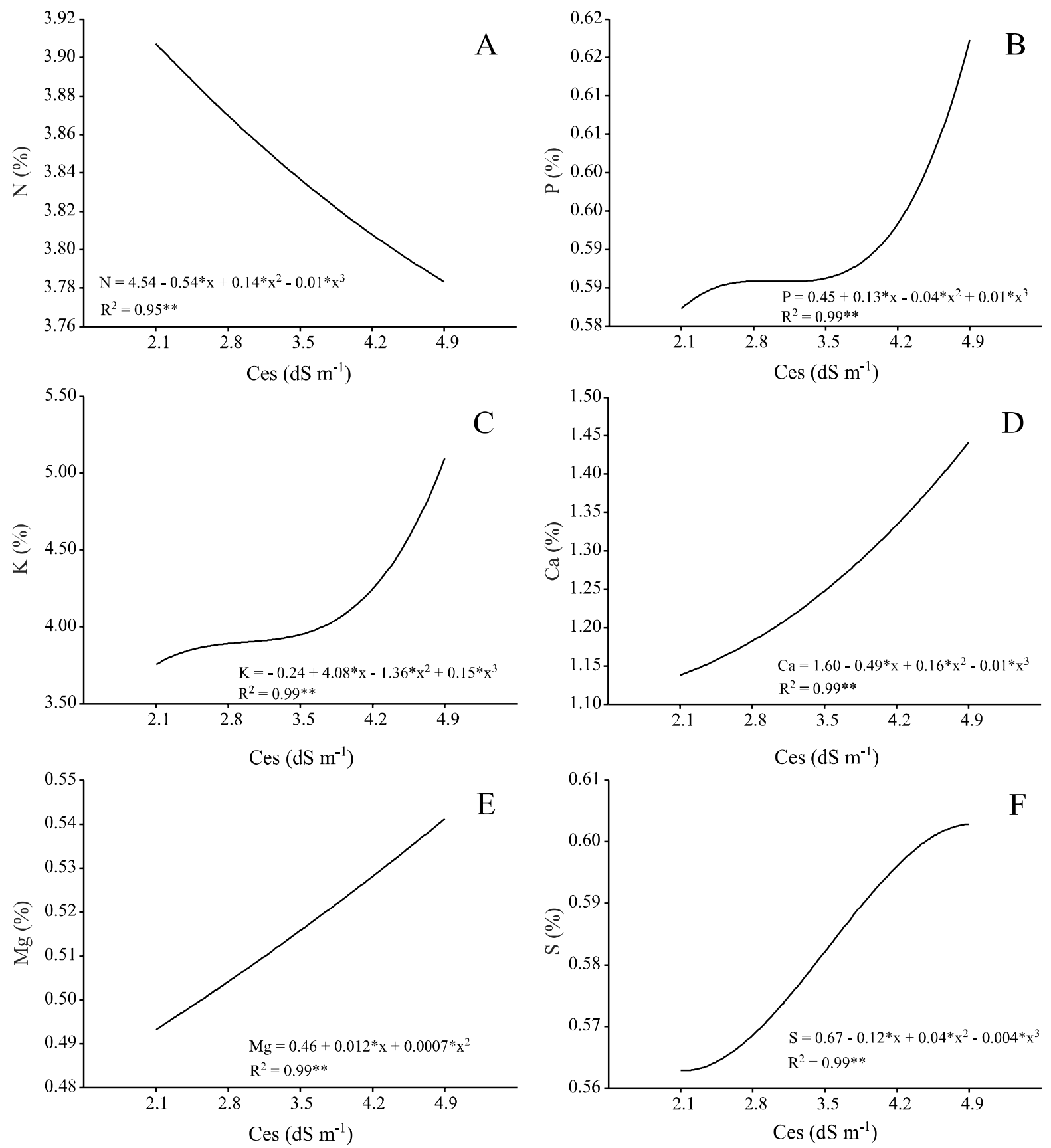

Potassium distribution was similar to that identified for phosphorus, i.e. an increase in concentration along with that of the ECs, mainly from an ECs equal to or greater than $3.5 \mathrm{dS} \mathrm{m}-1$ (Figure 1C). This increase is justified because potassium is the element most needed by the chrysanthemum, and therefore supplied in greater amounts in the nutrient solution $\left(293 \mathrm{mg} \mathrm{L}^{-1}\right)$. With regard to the

behavioural similarity of the data, potassium is similar to phosphorus as to absorption by the plant, since both rely on diffusion to reach the surface of the roots (MARSCHNER, 2005). From the mean values in Figure $1 C$, those plants situated between 3.75 and $5.09 \%$ were nutritionally balanced in potassium, and in accordance with the range of 3.5-5.0\%, recommended by Schoenmaker (1997). 
Calcium values also increased with the increase in ECs (Figure 1D), registering on average 20\% higher in plants irrigated with ECs $4.9 \mathrm{dS} \mathrm{m}{ }^{-1}$, compared to those grown under irrigation with ECs $2.1 \mathrm{dS} \mathrm{m}^{-1}$. Studies can be found in the literature (LACERDA et al., 2004; HU; SCHMIDHALTER, 2005) which confirm the reduction in calcium absorption as a deleterious effect of the electric conductivity of the substrate or irrigation solution: this was not seen in the present work. Marschner (2005) explains that the above effect should be ascribed to the sodium ion $\left(\mathrm{Na}^{+}\right)$, even resulting in deficiency of the element, and accounting for the result shown in Figure 1D, seeing as how sodium was not included in the solution being given, with the water used to make up the solutions being classified as low risk $\left(\mathrm{EC}<0.25 \mathrm{dS} \mathrm{m}^{-1}\right)$ by Ayers and Westcot (1999). Plants irrigated with ECs 2.1 and $2.8 \mathrm{dS} \mathrm{m}^{-1}$ presented calcium deficiencies, with values below the ideal adopted by Schoenmaker (1997) of 1.20 to $2.50 \%$, however symptoms of this deficiency were not observed.

The concentrations of magnesium and sulphur showed similar distributions, i.e. an increase in concentration with the increase in ECs (Figure $1 \mathrm{E}$ and $1 \mathrm{~F}$ respectively). This can be attributed to the source of sulphur used in the solution (MgSO4), which has magnesium as companion cation for sulphur absorbtion. The average concentrations presented for magnesium (0.25-1.0\%) and sulphur $(0.25$ to $0.70 \%)$ therefore are suitable for the chrysanthemum (SCHOENMAKER, 1997).

From the results of the variance analysis shown in Table 2 a significant difference can be seen between the substrates with (SWL) and with no (SNL) leaching for the tested micronutrients. Between the levels of electrical conductivity of the nutrient solution (ECs), there was a statistical difference for copper and zinc, with a significant interaction only being recorded for manganese.
Except for manganese in the SWL treatment (Figure 2C), regardless of the micronutrient, concentrations in the plants decreased with the increase in ECs (Figures 2A, 2B, 2C and 2D).

It can be seen that the micronutrients presented in Figure 2 are all cationic $\left(\mathrm{Cu}^{2+}, \mathrm{Fe}^{2+}, \mathrm{Mn}^{2+}\right.$ and $\left.\mathrm{Zn}^{2+}\right)$ and present common characteristics as to those factors that affect availability. The reduction in most cases is caused by such factors as an increase in $\mathrm{pH}$ and high levels of phosphorus (MARSCHNER, 2005). In general, comparing the curves of the micronutrients (Figure 2) with the phosphorus distribution (Figure 1B), it is seen that, particularly from ECs $3.5 \mathrm{dS} \mathrm{m}^{-1}$ on, the results are in accordance with Marschner (2005), since from the said ECs on, phosphorus concentrations were higher. In addition, organic matter in the substrate possibly also affects the availability and absorption of micronutrients, with a copper deficiency being common in organic soils even with high values of that element, with the same being seen for the complexation of manganese (MARSCHNER, 2005). Reductions in the respective concentrations of micronutrients as a function of the ECs were most significant for copper and zinc, in which those plants irrigated with ECs $4.9 \mathrm{dS} \mathrm{m}^{-1}$ presented $45 \%$ and $42 \%$ less copper and zinc respectively relative to those irrigated with ECs $2.1 \mathrm{dS} \mathrm{m}{ }^{-1}$. Among the studied micronutrients, these elements are below the sufficiency level for any ECs (copper) and for ECs 4.2 and $4.9 \mathrm{dS} \mathrm{m}^{-1}$ (zinc) as per the reference values from Schoenmaker (1997) for $\mathrm{Cu}$ (6-30 ppm) and $\mathrm{Zn} \mathrm{(20-250} \mathrm{ppm),}$ indicating that both were more influenced by the ECs than were the other micronutrients.

$\mathrm{Hu}$ e Schmidhalter (2005) recomendam a lixiviação como uma das possíveis opções para

Table 2 - Concentration of micronutrients in the aerial part of chrysanthemum plants cv. "Miramar" at 70 DAR, as a function of the leaching of the substrate solution (L), and electrical conductivity values of the nutrient solution (ECs). Jaboticabal, São Paulo

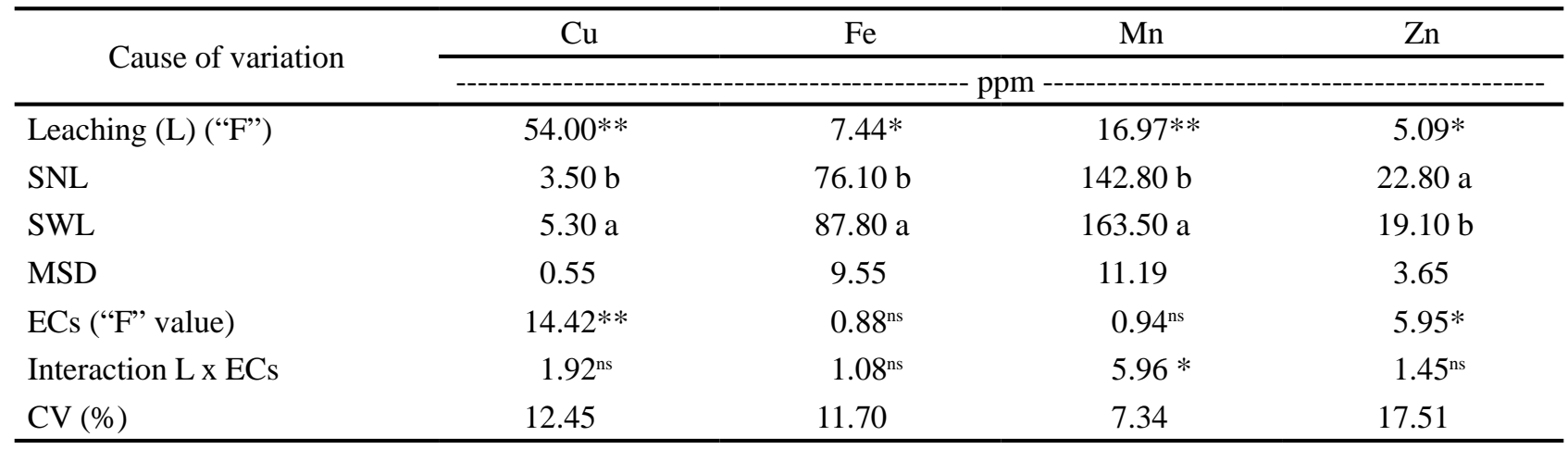

"F" = F value; $* *=$ significant at a $1 \%$ level of probability $(\mathrm{p}<0.01) ; *$ significant at a $5 \%$ level of probability $(0.01<\mathrm{p}<0.05) ; \mathrm{ns}=$ non-significant ( $>0.05) ; \mathrm{MSD}=$ minimum significant distance; $\mathrm{CV}=$ coefficient of variation; $\mathrm{SNL}=$ substrate with no leaching; $\mathrm{SWL}=$ substrate with leaching; ECs $=$ electrical conductivity of the nutrient solution 
Figure 2 - Concentration of copper (A), iron (B), manganese [(__ substrate with no leaching, (......) substrate with leaching] (C) and zinc (D) in the aerial part of chrysanthemum plants cv. "Miramar" at 70 DAR as a function of the values for electrical conductivity of the nutrient solution (ECs). Jaboticabal, São Paulo
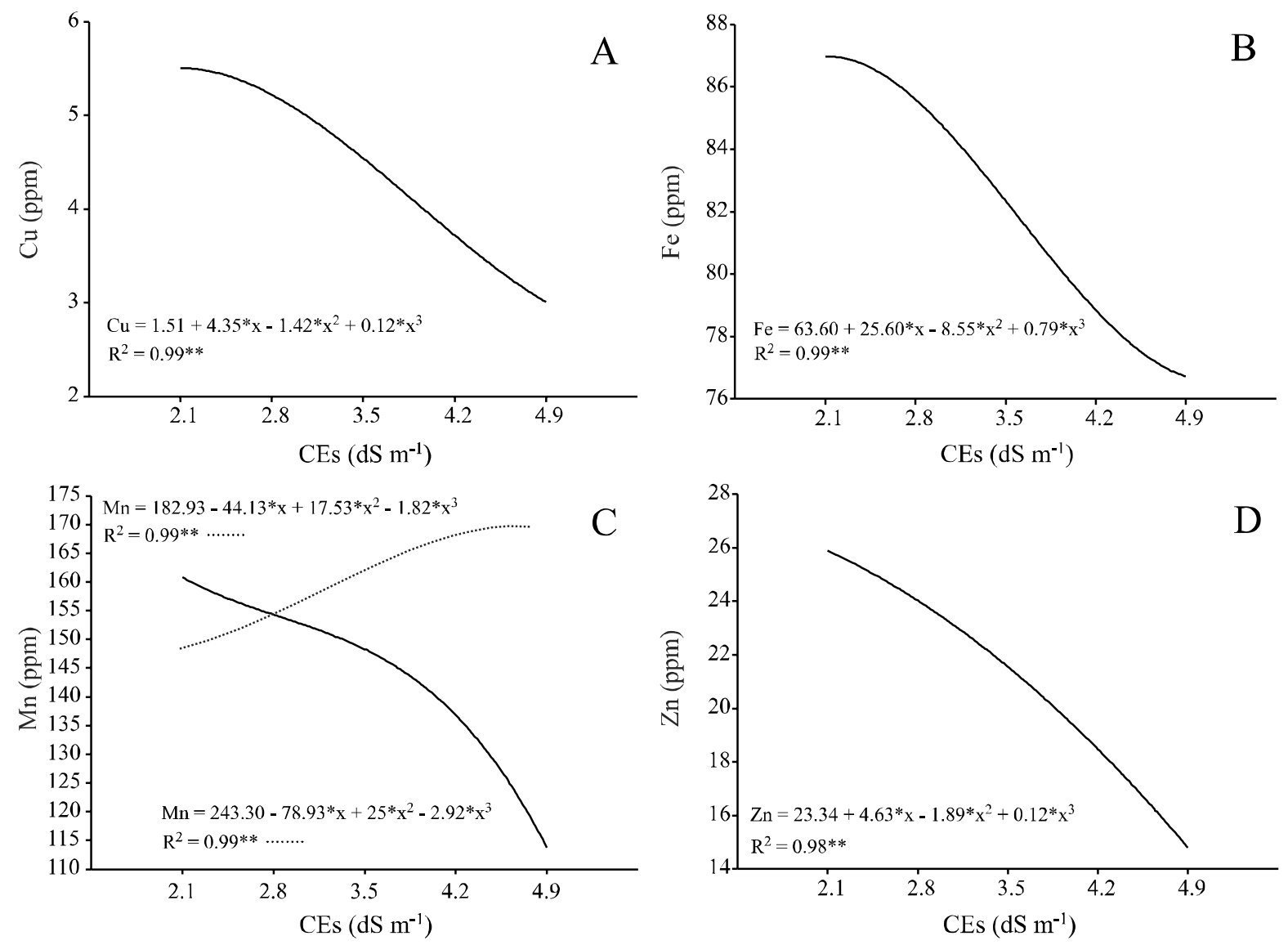

redução da condutividade elétrica na rizosfera e, consequentemente, evitar reações que $\mathrm{Hu}$ and Schmidhalter (2005) recommend leaching as one of the possible options for the reduction in electrical conductivity of the rhizosphere, and thus avoid reactions which are damaging to the mineral nutrition of the cultivated plant. From the results shown in Tables 1 and 2, it can be seen that the concentrations of calcium, sulphur and micronutrients were affected statistically by leaching.

The nutrients calcium, sulphur (Table 1) and zinc (Table 2) presented concentrations that were statistically higher in those treatments with no leaching. Marschner (2005) states that sulphur is absorbed by the plants in the form of the SO42- anion (supplied in this form by the solution) which is not retained by the soil and is easily leached. The opposite was observed for calcium, a cation which is less susceptible to leaching, and is confirmed

by the small difference between the averages of the SNL and SWL treatments, only $0.053 \%$.

For copper, iron and manganese, higher concentrations were recorded in plants under leaching (Table 2), also showing statistical superiority. Marschner (2005), reports that the organic matter of the substrate has an effect on the complexation of copper and manganese, retaining them and directly affecting the availability of these elements. Accordingly, the concentrations of the respective nutrients are not only influenced by leaching, but also the negative effect of phosphorus on absorption should emphasized, since for phosphorus the average in plants with no leaching was approximately $10 \%$ higher than in those with.

Iron was supplied in the form of powder and chelate and is an element which is directly connected to the cycling of oxygen, sulfur and carbon, thereby accounting for the higher concentration in those plants under leaching (Table 2). 


\section{CONCLUSIONS}

From the present study, it was concluded that:

1. An electrical conductivity of the nutrient solution of $3.5 \mathrm{dS} \mathrm{m} \mathrm{m}^{-1}$ can be indicated for potted chrysanthemum crops under the studied conditions;

2. Leaching of salts is recommended for potted chrysanthemum crops under the studied conditions.

\section{ACKNOWLEDGEMENTS}

The authors wish to acknowledge the financial support, in the form of scholarships awarded, of the Coordenação de Aperfeiçoamento de Pessoal de Nível Superior (CAPES), in the development of this research.

\section{REFERENCES}

AYERS, R. S.; WESTCOT, D. W. A qualidade da água na agricultura. Campina Grande: Universidade Federal da Paraíba, 1999. 153 p.

BARBOSA, J. G. et al. Concentração de nutrientes em crisântemo de corte, cultivados em hidroponia, sob diferentes doses de cálcio. Bioscience Journal, v. 25, n. 2, p. 46-54, 2009.

BARBOSA, M. S. et al. Concentração de nutrientes em crisântemos de vaso, cultivados sob fertirrigação, em resposta a doses de cálcio. Magistra, v. 20, n. 3, p. 273-279, 2008

BECKMANN-CAVALCANTE, M. Z. et al. Condutividade elétrica da solução nutritiva para o cultivo do crisântemo em vaso. Revista Brasileira de Ciência do Solo, v. 34, p. 747-756, 2010.

BECKMANN-CAVALCANTE, M. Z. et al. Soluções nutritivas no desenvolvimento do crisântemo cultivado em vaso. Irriga, v. 14, n. 2, p. 205-219, 2009.

BOSCO, M. R. O. et al. Influência do estresse salino na composição mineral de berinjela. Revista de Ciência Agronômica, v. 40, n. 2, p. 157-164, 2009.

CAVALCANTE, L. F. et al. Germinação de sementes e crescimento inicial de maracujazeiros com água salina em diferentes volumes de substrato. Revista Brasileira de Fruticultura, v. 24, n. 3, p. 748-751, 2002.

CAVINS, T. J. et al. Monitoring and managing $\mathrm{pH}$ and EC using the PourThru extraction method. Horticulture Information Leaflet, v. 590, p. 1-17, 2000.

FERNANDES, E. P. et al. Marcha de acúmulo de fósforo em crisântemo (Dendranthema grandiflorum T., Var. Salmon Reagan) no inverno. Pesquisa Agropecuária Tropical, v. 38, n. 1 , p. $27-31,2008$

FERREIRA, P. A. et al. Produção relativa do milho e teores folheares de nitrogênio, fósforo, enxofre e cloro em função da salinidade do solo. Revista Ciência Agronômica, v. 38, n. 1, p. 7-16, 2007.
FLOWERS, T. J. Improving crop salt tolerance. Journal of Experimental Botany, v. 55, n. 396, p. 307-319, 2004.

GIUFFRIDA, F.; LIPARI, V. Leaching irrigation to prevent salt accumulation in the substrate. Acta Horticulturae, n. 609, p. $435-440,2003$.

HU, Y.; SCHMIDHALTER, U. Drought and salinity: A comparison of their effects on mineral nutrition of plants. Journal of Plant Nutrition and Soil Science, v. 168, n. 4, p. 541-549, 2005.

JONES JUNIOR., J. B.; WOLF, B.; MILLS, H. A. Plant analysis handbook. Athens: Micro-Macro, 1991. 188 p.

JUNQUEIRA, A. H.; PEETZ, M. S. Mercado interno para os produtos da floricultura brasileira: características, tendências e importância socioeconômica recente. Revista Brasileira de Horticultura Ornamental, v. 14, n. 1, p. 37-52, 2008.

KIUNA, I.; ANGELO, J. A.; COELHO, P. J. Comércio exterior da floricultura brasileira em 2009: ponto de inflexão. Análises e Indicadores do Agronegócio, v. 5, n. 4, p. 2010.

LACERDA, C. F. et al. Influência do cálcio sobre o crescimento e solutos em plântulas de sorgo estressadas com cloreto de sódio. Revista Brasileira de Ciência do Solo, v. 28, n. 2, p. 289-295, 2004.

LANA, R. M. Q. et al. Produção de alface em função do uso de diferentes fontes de fósforo em solo do Cerrado. Horticultura Brasileira, v. 22, n. 3, p. 525-528, 2004.

MALAVOLTA, E.; VITTI, G. C.; OLIVEIRA, S. A. Avaliação do estado nutricional das plantas: princípios e aplicações. Piracicaba: Potafos, 1997. 319 p.

MARSCHNER, H. Mineral nutrition of higher plants. 2. ed. Orlando: Academic Press, 2005. 889 p.

MUNNS, R. Comparative physiology of salt and water stress. Plant Cell and Environment, v. 25, n. 2, p. 239-250, 2002.

PENNINGSFELD, F. Die Ernährung im Blumen und Zierpflanzenbau. 2. ed. Berlin: Parey, 1962. 217 p.

RODRIGUES, C. R. et al. Nutrição mineral, crescimento e teor de óleo essencial da menta em solução nutritiva sob diferentes concentrações de fósforo e épocas de coleta. Horticultura Brasileira, v. 22, n. 3, p. 573-579, 2004.

ROUDE, N.; NELL, T. A.; BARRET, V. E. Nitrogen source and concentration growing medium and cultivar affect longevity of potted chrysanthemums. HortScience, , v. 26, n. 1, p. 49-52, 1991.

SAS. SAS/STAT user's guide, version 4.0.2 SAS Inst. Inc., Cary, USA, 2000.

SCHOENMAKER, Van Z. Valores de referência para análise foliar no crisântemo na fase generativa. Agrifloricultura, 1997.

SPSS. SigmaPlot. Version 6.0.São Paulo, 2000. 1 CD-ROM.

YOKOI, S.; BRESSAN, R. A.; HASEGAWA, P. M. Salt stress tolerance of plants. JIRCAS Working Report, v. 23, n. 1, p. 25-33, 2002. 